\title{
SUURI VERKKOJATKOKERTOMUS
}

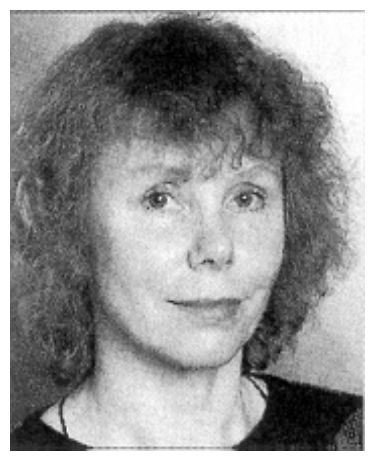

Anja Heikkinen
$\mathrm{M}$ uun median tavoin Aikuiskasvatus-lehtikin kohtaa ilman houkuttelua verkkoja ja verkostoja käsittelevien kirjoitusten ja kirjallisuuden ehtymättömän virran, mikä ei ole ihme vuosikausia kestäneen aktiivisen ja tukevasti resursoidun tietoyhteiskunta-, e-oppimis- ja verkostoitumisen edistämispolitiikan jälkeen. Suomalaisenkin koulutuksen ylevimmäksi tehtäväksi on tullut tehdä mahdolliseksi globaalin e-maailman toimivuus kasvattamalla siihen teknisesti ja tajunnallisesti kykeneviä ja halukkaita kansalaisia ja työntekijöitä. Uusseelantilaiset kasvatusfilosofit James Marshall ja Patrick Fitzsimons luonnehtivat jo 1990-luvun puolivälissä, kuinka jälkiteollisessa ja -modernissa maailmassa markkinoilla menestymisen kriittiseksi tekijäksi tulee endogeeninen talouskasvu, joka perustuu tuotannon kiihtyvään sisäiseen tehostamiseen ulkoisen laajenemisen ohella. Tieto- ja viestintätekniikan käyttöä oppimisen ja tiedon tuotteistamiseen ei tarvitse pitää tekniikan syynä, varsinkin kun tekniikka aina on ihmisten tekoa. Oleellisempaa on koulutuspoliittinen ja kasvatusideologinen ajattelu, joka osana yleisempää yhteiskuntapolitiikkaa määrittelee tieto- ja viestintätekniikan kehittämisen tavoitteita ja toteutusta. Marshall ja Fitzsimons luonnehtivat koulutuspolitiikkaa lähettäjä/vastaanottaja -yksilöiden kasvattamisen ohjelmina, jotka optimoivat kehoista irtaantuneen tiedon tuotannon hallinnoinnin globaalissa verkostoyhteiskunnassa ja -taloudessa. Koulutuksessa tieto- ja viestintätekniselle koneistolle on kehitelty omaa sanastoa - oppimisympäristöt, oppimisalustat - joka tuottaa vaikutelman sen käyttäjiä palvelevasta ja välineellisestä luonteesta. Bruno Latourin tavoin tieto- ja viestintäteknisen koneiston voi kuitenkin nähdä yhtenä keskeisenä toimijana ihmiset ja koneet yhdistävässä toimijajärjestelmässä. Erityistä tälle toimijalle on se, että se edellyttää muille toimijoille ominaisen analogisen toimintatavan koodaamista digitaaliseksi. Niin ihmisen ikävä toisen luo kuin kasvokkaisen kohtaamisen pelko saanee hänet mieluusti pitämään käyttöliittymää toisten ihmisten edustuksena.

Tuotannollisesti ja liiketoiminnallisesti menestyvät innovaatiot ovat ennenkin toimineet välitöntä sovellustaan laajempina inhimillisen toiminnan malleina. Esimerkiksi mekaanisen tehdasteollisuuden leviäminen säteili organisaatioiden ja yhteiskunnan hallinnointitapoihin. Tehtaan mekaanisen koneiston tuottavuus vaati sitä tehokkaasti palvelevan inhimillisen koneiston, joka oli sosiaalisesti oikein organisoitu johtoportaasta lattiatasolle. Ihmisten käsittelystä tuli entistä pysyvämpi osa työn johtamista ja organisaatiota ja alan asiantuntijoiden kysyntä kasvoi. Tehdastuotannossa menestyksensä osoittaneesta toimintamallista tuli koulutuksessakin yhtäl̈ltä kasvatuksen päämääriä, toisaalta käytänteitä muotoilevan esikuva.

Endogeenisessa taloudessa tieto- ja viestintätekniikan tehokkaasta hyödyntämisestä ja innovaatioiden tuotannosta on tullut kriittisiä menestystekijöitä. Käyttäjien toiminnan verkostomainen organisaatio on siinä välttämätöntä, var- 
sinkin innovatiivisessa tiedontuotannossa. Ihmisten oppimisen ja yhteistyön ohjaamisessa on niiden toimivuus tieto- ja viestintätekniikan käytön ja innovatiivisen tiedontuotannon tärkeintä. Alan osaajille ovat työmarkkinat olleetkin otolliset vuosikausia. Tietotekniikkaan ja verkostoihin perustuvan tuotannon malli on vauhdilla levinnyt kaikkeen inhimilliseen toimintaan, erityisen sujuvasti suomalaisen koulutuksen eri osa-alueille. Toki se on tapahtunut laite- ja ohjelmistotoimittajien ärhäkän markkinoinnin ja mainonnan ja niitä tukevan median ja politiikan ansiosta, mutta ehkä kyse on myös digitaalisen teknologian ja verkostotoiminnan kulttuurisesta lupauksesta ja esikuvallisuudesta.

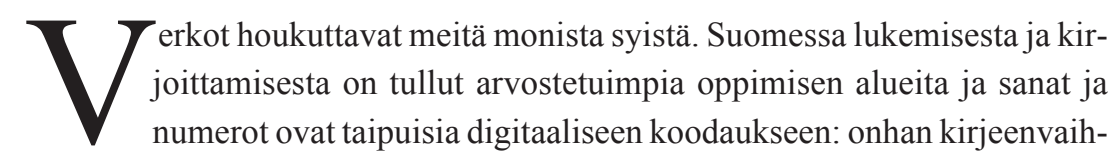
to- koneen kanssa verkkotoiminnan keskeisin muoto. Ehkä muiden kuin tekstuaalisen yhdessä olemisen tapojen vaikeus tekee jäsenyyden digitalisoidussa merkkiyhteiskunnassa helpommin hyväksytyksi. Tukeeko siihen myös taiteen, median ja tutkimuksen jälkimoderni kertomus meistä aikaan ja paikkaan sitoutumattomina yksilöinä ja omien merkitysmaailmojemme rakentajina? Vai houkuttaako aina uusia muotoja saava edistyksen ja demokratian utopia, jonka edelliset versiot näyttivät romahtaneen? Ovathan tieto- ja viestintätekniikka ja innovatiiviset tietoyhteisöt antaneet mahdollisuuden ylläpitää yhteisöllisyyden, tasa-arvoisuuden ja jakamisen retoriikan jatkuvuutta.

Jos tieto- ja viestintätekniset verkot ja verkostot ovat osa ihmisten, muun luonnon ja teknisten olioiden muodostamia toimijajärjestelmiä, ei niiden hyvyyttä ja huonoutta tarvitse pitää niiden itsensä ominaisuuksina. Digitaalista koneistoa ei voine syyttää Myyrmannin tapahtumista, eikä sille voine antaa ansiota myöskään osaavasta rakentamisesta, sairaiden hoidosta, siisteyden ylläpitämisestä, hyvästä ruoasta, ystävyydestä. Arvelen, että verkko-oppijuuden, -työntekijyyden ja -kansalaisuuden merkitys riippuu verkkojen ulkopuolisesta elämästä. Kertomuksia ja tutkimuksia aikuiskasvatuksen suhteesta verkko-oppimiseen ja verkostotoimintaan tarvitaan.

\section{Anja Heikkinen}

